\title{
Novos hospedeiros de Fuligo septica no Estado do Maranhão
}

\author{
Gilson Soares da Silva , Isabel Cristina Madeira Ferreira, Natália Véras Bitencourt
}

Universidade Estadual do Maranhão, Departamento de Fitotecnia e Fitossanidade, 65001-970, São Luís - MA. gilson_soares@uol.com.br Autor para correspondência: Gilson Soares da Silva

Data de chegada:11/01/2007. Aceito para publicação em:02/05/2007

Em novembro de 2006, foram coletadas na horta da Fazenda Escola da Universidade Estadual do Maranhão, em São Luís, plantas de alface (Lactuca sativa L.), couve (Brassica oleracea var. acephala DC ) e melancia [Citrullus lanatus (Thumb.) Matsum \& Nakai], apresentando as folhas recobertas por um crescimento de coloração brancoacinzentada, formando crostas facilmente destacáveis com o auxílio de um estilete (Fig. 1-A,B). Além dessas plantas cultivadas, folhas mortas de Eucalyptus sp. e folhas vivas da planta daninha apaga-fogo (Alternanthera sp.) exibiam sintomas semelhantes (Fig.1-C). Exame microscópico dos materiais revelou que a crosta era constituída de colônias anfígenas, irregulares, cinérias, com produção de esporos negros em massa, elipsóides, medindo em média 10 x $12 \mathrm{~mm}$. De acordo com essas características, o organismo foi identificado como Fuligo septica (L.) Wiggers (Teixeira,A.R. Gêneros de Myxomicetes. Rickia, São Paulo, supl. 4, p. 48-49, 1971), um Myxomycete com ampla distribuição no mundo, ocorrendo sobre inúmeros substratos incluindo folhas em decomposição, madeira apodrecida, troncos de árvores e, eventualmente, plantas cultivadas sem, no entanto, serlhes patogênico (Alexopoulos, C.J. ; Mims,C.W. Introductory Mycology. $3^{\text {th }}$ ed. New York:Wiley, 1979.632 p.). A ocorrência desse fungo já foi relatada no Maranhão sobre alface e coentro de caboclo (Eryngium foetidum L.) (Silva,G.S. ; Bezerra. J.L. Fitopatologia Brasileira, v.30, p.439,2005) e no Brasil em outros poucos hospedeiros (Mendes et al. Fungos em plantas no Brasil Brasília: Embrapa-SPI/Embrapa Cenargen, 1998. 569 p.). Apenas em alface, cujas folhas tornaram-se impróprias para a comercialização, $F$. septica causou danos econômicos. Este relato acrescenta mais três hospedeiros desse interessante organismo no Brasil.

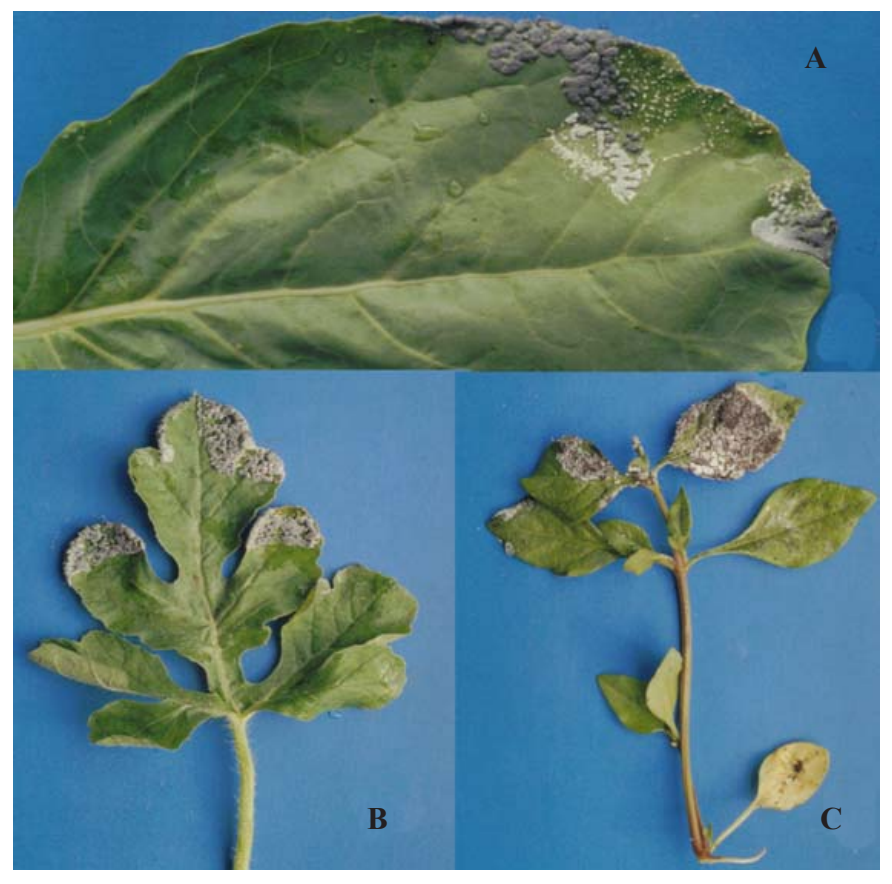

Figura 1. Sintomas causados por Fuligo septica em couve (A), melancia (B) e Alternanthera sp. (C). 